\title{
TINDAKAN PREVENTIF ORANG TUA TERHADAP PERGAULAN BEBAS DI KALANGAN REMAJA KRISTEN SUATU PENGAMATAN DI GKII EFATA AIRMADI DI MANADO
}

\author{
Esti Christiana Watta \\ sttjaffraymakassar@yahoo.co.id \\ Ivone Bonyadone Palar \\ ivonepalar@ymail.com
}

\begin{abstract}
ABSTRAK
Sesuai dengan permasalahan yang ada, maka tujuan penulisan karya ilmiah ini adalah: Pertama, Menemukan faktor-faktor pemicu para remaja Kristen terlibat dalam pergaulan bebas. Kedua, Menjelaskan tentang bahaya-bahaya dari pergaulan bebas bagi remaja Kristen. Ketiga, Menemukan pedoman atau langkah- langkah tindakan preventif bagi orang tua agar remaja tidak terjerumus dalam pergaulan bebas.

Adapun metode penulisan yang digunakan dalam penulisan karya ilmiah ini untuk mendapatkan data yang diperlukan adalah: menggunakan metode wawancara dan metode penelitian buku-buku perpustakaan. Wawancara adalah salah satu bagian yang terpenting dari setiap survai. Tanpa wawancara penelitian akan kehilangan informasi yang hanya dapat di peroleh dengan jalan bertanya langsung kepada responden, wawancara merupakan suatu proses interaksi dan komunikasi.

Berdasarkan hasil pembahasan maka penulis menarik kesimpulan sebagai berikut: Faktor pemicu yang menyebabkan remaja jatuh dalam pergaulan bebas adalah (1) Pola asuh orang tua. Pada umumnya pola asuh orang tua mengikuti tradisi yang telah ada yaitu membesarkan anak dan member fasilitas pendidikan formal, tetapi tidak memperhitungkan kebutuhan perkembangan anak yang memerlukan komunikasi tentang pendidikan seks untuk membentengi dirinya dari akibat pergaulan bebas. Karena itu dianggap tidak perlu atau "tabu" diperbincangkan sebelum sebelum anak dewasa atau menikah. (2) Perkembangan teknologi. Remaja yang tidak mendapatkan ppendidikan seks dari orang tua mudah tergiur dan terjebak oleh informasi dari dunia teknologi karena apa yang mereka dapatkan dari informasi yang terus berkembang diluar dan akibatnya teknologi tidak lagi sebagai pemberi informasi tetapi sebagai "panutan" yang menjawab kebutuhan remaja. (3) Teman sebaya. Ikatan yang kuat antara remaja dengan teman sebaya serta lingkungan mereka yang menghalalkan segala cara untuk menikmati masa remaja dapat membawa remaja kepada pergaulan bebas.
\end{abstract}

Kata kunci: Tindakan preventif, orang tua, pergaulan bebas, kalangan remaja 


\section{PENDAHULUAN}

\section{Latar Belakang Masalah}

Betapa mulianya Allah memberikan kepada orang tua anak-anak remaja untuk dibesarkan. Masa remaja adalah masa di mana ada rasa tidak aman yang luar biasa di mana remaja tidak mempunyai kepastian bagaimana untuk bertindak. Anak-anak remaja merasa rentan terhadap setiap hal, mereka cemas tentang pemahaman mereka akan kehidupan. Masa-masa ini merupakan kesempatan yang sangat berharga bagi orang tua bahkan gereja untuk memberikan dukungan yang positif dalam berbagai segi kepada para remaja tersebut. Bila seluruh masa hidup seseorang diamati, maka masa remaja merupakan masa di mana terjadinya proses-proses yang paling banyak menghasilkan perubahan baik yang langsung tampak atau hanya dirasakan akibatnya oleh diri sendiri dan orang lain. ${ }^{2}$ Dalam masa-masa remaja seperti ini pergaulan merupakan hal yang sangat dibutuhkan oleh remaja, di mana pada masa ini para remaja sedang mencari jati diri mereka, sehingga mereka akan merasa ada sesuatu yang kurang ketika mereka tidak bergaul dengan teman-teman sebaya mereka, mereka akan merasa sebagai orang yang "kuper" artinya kurang pergaulan dan ini akan membuat mereka merasa tidak nyaman. Sehingga tanpa berpikir panjang dan hanya ingin agar diakui sebagai orang yang "gaul" sehingga menimbulkan sesuatu yang negatif.

Seperti yang penulis amati di Airmadidi. Ada beberapa anak muda yang berpacaran bebas seperti: dimulai dengan berpegangan tangan, ciuman sampai masuk pada percumbuan dan akhirnya sampai pada melakukan hubungan seks.

Menurut G. Konopka, masa remaja merupakan fase yang paling penting dalam pembentukan nilai. Pembentukan nilai merupakan suatu proses emosional dan intelektual yang sangat dipengaruhi oleh interaksi sosial. ${ }^{3}$ Memang pada masa ini para remaja sedang mencari jati diri mereka, mereka akan berusaha untuk bergaul serta menarik perhatian sehingga akan banyak orang yang simpati kepada mereka dan seringkali para remaja tidak lagi memikirkan apakah pergaulan yang di jalani membawa pengaruh yang baik atau buruk yang paling penting dalam pikiran mereka adalah memiliki banyak teman dan bahagia dalam

${ }^{1}$ Tedd Tripp. Shephering A Child Heart-Menggembalakan Anak Anda (Malang: Gandum Mas,2002), 264-265.

${ }^{2}$ Y. Singgih D. Gunarsa dan Singgih D Gunarsa, Psikologi Untuk Muda-Mudi (Jakarta: BPK Gunung Mulia,1991), 36.

${ }^{3}$ Singgih D Gunarsadan Y Singgih D Gunarsa, Psikologi Perkembangan Anak dan Remaja (Jakarta: BPK Gunung Mulia,1991),214. 
pergaulan mereka. Berbicara mengenai pergaulan remaja, banyak juga hal-hal yang bisa terjadi seperti semakin moderennya perkembangan teknologi sehingga para remaja banyak menggunakan fasilitas-fasilitas yang canggih yang dinikmati oleh remaja, tetapi akan berbahaya ketika para remaja mengkonsumsi informasi ataupun hal-hal yang negatif yang berbau seks sehingga ketika mereka melihat maka itu akan tertanam dalam memori mereka dan selalu diingat ketika hal ini terjadi para remaja akan tergiur dan terjerumus kedalam pergaulan bebas yang salah satunya adalah free sex atau seks bebas. ${ }^{4}$

Awasan Firman Tuhan dalam I Korintus 15:33 yang mengatakan, "Janganlah kamu sesat: Pergaulan yang buruk merusak kebiasaan yang baik," seharusnya membentengi para remaja untuk tidak terjerumus dalam pergaulan bebas yang menyesatkan. Namun godaan dalam pergaulan sangat kuat sehingga remaja dengan mudah melupakan nasihat Firman Tuhan tersebut.

Seperti kasus di bawah ini, dimana penulis melakukan wawancara kepada salah satu orang tua yang memiliki anak remajanya yang jatuh dalam hubungan seks bebas dan bagaimana orang tua tersebut menyikapinya. Menurut orang tua yang penulis wawancara mengatakan awalnya dia merasa kecewa dan marah, tetapi dia menyadari kalau memarahi anak remajanya akan membawa luka lebih dalam terhadap remaja tersebut, oleh sebab itu orang tua tersebut akan merangkul dan menerima anaknya dan menyelesaikan masalah yang dialami anaknya dengan sabar.

Tentunya ketika seorang anak yang sudah menanjak remaja orang tua akan merasa kuatir dan takut karena anak remajanya sudah memiliki banyak kegiatan diluar rumah dan orang tua tidak memantau terus apa yang dilakukan anaknya di luar dan ketakutan lain dari orang tua yaitu ia takut kalau anaknya akan salah bergaul dan jatuh dalam pergaulan bebas. ${ }^{6}$

Dengan melihat situasi dan kondisi para remaja saat ini maka diperlukan adanya suatu tindakan untuk mengantisipasi agar para remaja Kristen ini tidak terjerumus dan tergoda kedalam pergaulan bebas. Maka atas dasar alasan ini penulis memilih judul "Tindakan Preventif Orang Tua Terhadap Bahaya Pergaulan Bebas Di Kalangan Remaja Kristen (Suatu Pengamatan Di GKII Efata Airmadidi- Manado)."

\footnotetext{
${ }^{4}$ Roswita Ndrah dan JuliantoSimanjuntak, 9 Masalah Utama Remaja (Tangerang: YAPKI,2009), 98.

${ }^{5}$ Lely B, Percakapan telepon dengan penulis, 20 Mei 2012.

${ }^{6}$ Rina Puasa, Percakapan telepon dengan penulis, 27 Mei 2012.
} 


\section{Pokok Masalah}

Berdasarkan penjelasan pada latar belakang di atas, maka yang akan menjadi pokok masalah dalam penulisan ini adalah: Pertama, Apakah faktor-faktor pemicu para remaja Kristen terlibat dalam pergaulan bebas? Kedua, Apa bahaya- bahaya dari pergaulan bebas bagi remaja Kristen? Ketiga, Bagaimana tindakan orang tua dalam membentengi atau mencegah anak remajanya agar tidak terjerumus dalam pergaulan bebas?

\section{Tujuan Penulisan}

Penulis tergerak untuk menulis mengenai bahaya pergaulan bebas di kalangan remaja Kristen dengan tujuan yaitu : Pertama, Menemukan faktor-faktor pemicu para remaja Kristen terlibat dalam pergaulan bebas. Kedua, Menjelaskan tentang bahaya- bahaya dari pergaulan bebas bagi remaja Kristen. Ketiga, Menemukan pedoman atau langkahlangkah tindakan preventif bagi orang tua agar remaja tidak terjerumus dalam pergaulan bebas.

\section{Manfaat Penulisan}

Beberapa manfaat yang hendak dicapai sehubungan dengan penulisan penelitian ini yaitu: Pertama, Agar tulisan ini berguna bagi pembaca yang ingin mendapatkan informasi mengenai perggaulan bebas dikalangan remaja. Kedua, Sebagai suatu wawasan bagi para remaja, orang tua, masyarakat dan gereja dalam mengantisipasi bahaya yang diakibatkan dari pergaulan bebas dalam hal ini seks bebas.

\section{Metode Penelitian}

Dalam penulisan penelitian ini, penulis menggunakan metode wawancara dan metode penelitian buku-buku perpustakaan. Wawancara adalah salah satu bagian yang terpenting dari setiap survai. ${ }^{7}$

\section{Batasan Penulisan}

Dalam penulisan Penelitian ini, Penulis hanya membahas mengenai pengertian pergaulan bebas dalam hal ini "free sex" atau seks bebas dikalangan remaja Kristen usia 13-18 tahun, bahaya-bahaya dari free sex dan bagaimana tindakan preventif atau pencegahan orang tua agar anaknya tidak terlibat dalam pergaulan bebas tersebut.

\footnotetext{
${ }^{7}$ Sangarimbun Masri dan Sofian Effendi, Metode Penelitian Survai (Jakarta: LP3Es,1986), 145.
} 


\section{METODE PENELITIAN}

\section{Gambaran Umum Lokasi Penelitian}

Dalam metodologi penelitian penulis akan menguraikan sekilas tentang lokasi penelitian yang penulis ambil yaitu di: Gereja Kemah Injil Indonesia (GKII) jemaat "Efata" Airmadidi, Manado- Sulawesi Utara, yang beralamat di Jl. Arnold manonutu Sarongsong II. Lingkungan IV, Kec.Airmadidi.

\section{Sejarah Singkat Berdirinya GKII “ Efata “ Airmadidi}

GKII "Efata” Airmadidi pada awalnya adalah sebagai Pos PI yang dicetuskan oleh Pdt. Jeremia Djadi, S.Th pada tahun 1983. Danpadatanggal 18 Juli 1985 menjadi jemaat lokal yang di pimpin oleh Pdt. Berti Kambey, M.Div sebagai ketua jemaat dari tahun 1985- 2007. Dan pada tahun 2007 kepemimpinan di jemaat Efata Airmadidi digantikan oleh Pdt. Febe Kambey Sutanto, S.Th dengan Jumlah anggota jemaat sampai tahun 2012 ialah 210 jiwa dengan 70 Kepala Keluarga.

\section{Sejarah Singkat Berdirinya Remaja Efata}

Awalnya disebut AMKI yang adalah singkatan dari Angkatan Muda Kemah Injil yang memiliki anggota dari SMP- Perguruan Tinggi. Digabung dengan pemuda dari SMP sampai Perguruan Tinggi. AMKI yang dibentuk pada tahun 1989, tetapi ibadah ini lambat laun tidak berjalan dengan baik. Namun pada tahun 2004 kembali lagi dibentuk AMKI yang dipimpin oleh: Bpk. Gayu Kamalaheng. Yang memiliki jumlah anggota 35 orang. Dan pada tahun 2011 kegiatan ibadah remaja sudah dipisah dengan ibadah pemuda, dengan dikoordinator langsung oleh ibu Gembala. Ibadah remaja diadakan pada hari senin jam 5 sore dengan jumlah anggota 25 orang. Kegiatan yang dilakukan dalam ibadah yaitu sharing FirmanTuhan, khotbah atau renungan, games, pujian dan Penyembahan.

\section{Jenis Penelitian}

Jenis penelitian yang digunakan oleh penulis adalah penelitian kualitatif. Data ini menunjukkan kualitas atau mutu sesuatu yang ada, berupa keadaan, proses, kejadian atau peristiwa dan lain- lain yang dinyatakan dalam bentuk perkataan. ${ }^{8}$

${ }^{8}$ Hadari Nawawi Martini Hadari, Instrumen Penelitian Bidang Sosial. (Yogyakarta: Gajah Mada University Press,1992), 43. 


\section{Populasi dan Sampel \\ Populasi}

Populasi adalah seluruh penduduk yang dimaksudkan untuk diteliti. ${ }^{9}$ Dalam penelitian ini yang menjadi populasi adalah orang tua dan remaja di GKII "Efata” Airmadidi.

\section{Sampel}

Sampel adalah bagian dari populasi. Sampel adalah penduduk yang jumlahnya kurang dari polulasi. Jadi sampel adalah bagian dari populasi atau yang mewakili secara keseluruhan dari populasi, maka penelitian yang dilakukan terhadap sampel itu pada umumnya bertujuan untuk menarik kesimpulan tentang populasi. ${ }^{10}$ Jumlah sampel yang diambil ialah 5 orang tua dan 5 remaja.

\section{Teknik Pengumpulan Data Wawancara}

Dalam penulisan karya ilmiah ini penulis melakukan teknik wawancara, wawancara adalah penelitian yang tertuang dalam daftar pertanyaan dan situasi wawancara. ${ }^{11}$ Wawancara merupakan suatu proses interaksi dan komunikasi. Dalam proses ini hasil wawancara ditentukan oleh beberapa faktor yang berinteraksi dan mempengaruhi arus informasi. Faktor-factor tersebut ialah : pewawancara, responden, topik penelitian yang tertuang dalam daftar pertanyaan dan situasi wawancara.

Melalui penelitian tersebut penulis mengumpulkan data dengan cara wawancara langsung yang dilakukan lewat telepon. Wawancara adalah daftar pokok materi yang akan ditanyakan kepada informan, daftar materi merupakan garis besar pertanyaan yang kemudian dapat berkembang pada waktu sedang di lakukan proses wawancara. ${ }^{12}$ Wawancara adalah tanya jawab yang dilakukan dengan seseorang untuk memperoleh informasi, data yang diperlukan, antara wartawan dan pejabat, antara peneliti dengan nara sumber, antara direksi perusahan dengan stafnya atau pelamar pekerjaan. ${ }^{13}$

\footnotetext{
${ }^{9}$ Sugiono, Statistika Untuk Penelitian. (Bandung: CV. Alfabeta, 2007), 15.

${ }^{10}$ Sutrisno Hadi, Statistik. (Yogyakarta: FIP-IKIP,1975),3.

${ }^{11}$ Masri Sangarimbun \& Sofian Effendi, Metode Penelitian Survai (Jakarta: LP3Es,1986), 145.

${ }^{12}$ Husain Usman, Metodologi Penelitian Sosial (Jakarta: Bumi Aksara,1998), 57.

${ }^{13}$ J.S Badudu \& $\&$ Sutan Mohammad Zain, Kamus Umum Bahasa Indonesia "vs Wawancara (Jakarta: Pustaka Sinar Harapan, 1994), 1624.
} 


\section{Observasi}

Observasi adalah teknik pengumpulan data yang dilakukan melalui suatu pengamatan dengan disertai pencatatan keadaan atau perilaku objek sasaran. ${ }^{14}$ Jadi penulis mengadakan pengamatan dan mencatat apa yang terjadi di lokasi penelitian.

\section{Teknik Analisis Data}

Data yang diperoleh melalui wawancara penulis dengan responden yang di jabarkan dengan cara interpretasi dan dekarya ilmiah, tentang tindakan preventif orang tua terhadap pergaulan bebas remaja Kristen. Dan penulis menganalisa data tersebut dengan mengelola dan menyimpulkan dalam bentuk uraian.

\section{Interpretasi}

Interpretasi dalam Kamus Besar Bahasa Indonesia adalah pemberian kesan, pendapat, atau pandanagan teoretis terhadap sesuatu, tafsiran. interpretasi adalah pemberian kesan, pendapat atau pandangan teoritis terhadap suatu tafsiran. ${ }^{15}$ Setelah melakukan penelitian maka penulis akan mengambil suatu kesimpulan terhadap hasil penelitian yang dilakukan.

Dan berdasarkan pernyataan tersebut, melalui karya ilmiah ini penulis tidak hanya membahas masalah yang terjadi dilapangan, tetapi penulis juga berusaha mencari jalan keluar yang terjadi dilapangan. Jalan keluar yang penulis paparkan adalah mengenai tindakan pencegahan agar remaja tidak terlibat dalam pergaulan bebas (seks bebas). Dalam hal ini bagaimana orang tua melakukan perannya untuk mengantisipasi agar anak remajanya tidak terjerumus dalam seks bebas. Dengan kata lain tindakan preventif bukan pengobatan.

\section{Dekarya ilmiah}

Untuk mendapatkan hasil yang akurat dan efisien dalam karya ilmiah, penulis menggunakan teknik analisa data dekarya ilmiah, karena dengan menggunakan teknik dekarya ilmiah penulis dapat dekat dengan data sebagai mana aslinya (dicatat atau direkam). Dekarya ilmiah ialah menjawab pertanyaan "apa yang terjadi disini?" berdasarkan data yang dilaporkan orang lain. ${ }^{16}$

\footnotetext{
${ }^{14}$ Masri Sangarimbun \& Sofian Effendi, Metode Penelitian Survai (Jakarta: LP3Es,1986), 192.

${ }^{15}$ Kamus besar bahasa Indonesia, s.v. "Interpretasi”.

${ }^{16}$ Andreas B. Subagyo, Pengantar Riset Kualitatif dan Kuantitatif (Bandung: YayasanKalamHidup, 2004), 62.
} 


\section{ANALISIS HASIL PENELITIAN DAN PEMBAHASAN}

Dalam penelitian yang dilakukan oleh penulis, penulis melakukan wawancara dengan orang tua sebanyak 5 orang dan kepada 5 orang anak, yang pada masa remajanya telah melakukan hubungan seks pranikah. Maka dari hasil penelitian yang diperoleh akan dibahas pada bagian ini dengan menganalisa dan mengemukakan beberapa pertanyaan yang diajukan oleh penulis sehubungan dengan judul yang diambil atau yang di angkat.

Lewat wawancara yang dilakukan kepada 5 orang anak remaja dan didapati bahwa merek telah melakukan hubungan seks, yang sudah melakukan hubungan dapat dijelaskan dalam bentuk uraian sebagai berikut:

Setelah melakukan wawancara sesuai pertanyaan yang telah disiapkan kepada 5 orang remaja tersebut, mereka mengerti dengan apa yang dinamakan pergaulan bebas. Mereka juga mengerti mengenai seks dan sesuai pengakuan bahwa mereka telah melakukan hubungan seks yang awalnya dari rayuan- rayuan, ciuman, kata- kata yang romantis sampai pada melakukan hubungan seks. Setelah ditanyakan apakah mereka mendapatkan pendidikan seks dari orang tua maka mereka mengatakan bahwa mereka tidak mendapatkan pendidikan seks yang cukup di dalam lingkungan keluarga. Mereka mendapatkan hal- hal mengenai seks kebanyakan dari teman sekolah dan menonton film- film yang pornografi. Ternyata hal ini terekam dengan baik dimemori, sehingga mereka terjebak untuk melakukan hubungan seks dengan kekasih mereka secara sembunyi- sembunyi agar tidak diketahui oleh orang tua. Ada bahaya- bahaya yang timbul dari perilaku tersebut mengakibatkan:

Pertama, dua orang mengalami bahaya fisik dan sosial yaitu dua orang hamil diluar nikah: satu orang terjebak melakukan aborsi dan satu orang lagi menikah tetapi mereka berdua mengalami juga bahaya kejiwaan dan perilaku yaitu merasa malu, bersalah, menyesal, ingin bunuh diri dan merasa tertuduh.

Kedua, satu orang mengalami bahaya ekonomi terpaksa menikah diusia dini dan mengalami kesulitan untuk menghidupi keluarga akibatnya ia mereka rela bekerja apa saja untuk menghidupi keluarganya.

Ketiga, tiga orang mengalami bahaya kejiwaan dan perilaku yaitu merasa bersalah dan menyesal. namun tidak diketahui oleh keluarga dan lingkungannya. 
Setelah penulis melakukan wawancara kepada orang tua yang memiliki anak remaja baik yang terlibat dalam seks bebas maupun yang tidak, dimana ketika mewawancarai orang tua yang anaknya sudah terlanjur melakukan seks bebas maka selaku orang tua tentunya ada perasaan kecewa karena apa yang diharapkan orang tua kepada anak tidak tercapai, namun sebagai orang tua mereka sadar bahwa ketika mereka menolak anak mereka maka masalah akan semakin rumit dan akhirnya orang tua menerima keberadaan anaknya dengan lapang hati dan mencari jalan keluar agar masalah yang dihadapi memperoleh jalan keluar. Sebagian orang tua yang memiliki anak remaja mengaku bahwa mereka telah memberikan pendidikan seks kepada anak mereka sejak kecil, dan mengajarkan anak dalam hal kerohanian seperti membawa mereka ke ibadah sekolah minggu serta mengajarkan dan memberi nasehat mengenai hal- hal yang harus mereka lakukan dan yang tidak boleh mereka lakukan. Selaku orang tua hal yang harus dilakukan agar anak remaja mereka tidak jatuh dalam pergaulan bebas maka ada tindakan pencegahan yang harus orang tua lakukan. Karena para orang tua tersebut telah melihat kejadian yang terjadi kepada sebagai anak remaja yang telah terjerumus dalam tindakan seks pranikah, maka selaku orang tua yang memiliki anak remaja mereka memberikan standar- standar moral kepada anak- anak mereka. Orang tua juga memberikan kasih sayang serta berusaha untuk memenuhi apa yang menjadi kebutuhan anak secara keseluruhan. Selaku orang tua mereka juga sangat mengerti kalau anak- anak saman sekarang membutuhkan seorang figur yang menjadi sahabat bagi mereka, maka selaku orang tua mereka mengaku bahwa mereka berusaha untuk menjadi sahabat yang baik yang dengan sabar mendengarkan segala keluhan- keluhan anak mereka untuk mencurahkan segala isi hati kepada orang tua dan hal ini butuh keseriusan orang tua agar anak mereka merasa dipercaya dan mempercayai mereka selaku orang tua. Ini juga menjadi suatu awasan bagi orang tua ketika akhirnya bila sesuatu yang tidak diinginkan juga bisa terjadi maka orang tua sudah siap untuk menolong anak mereka.

\section{KESIMPULAN ANALISIS DATA}

Berdasarkan hasil wawancara dan pengamatan langsung di lapangan, maka berikut ini penulis akan memaparkan kesimpulan analisis dengan menggunakan nama-nama samara, sebagai berikut:

Pertama, Akibat secara fisik yang dialami ketika melakukan seks bebas adalah (1) Terjadinya kehamilan. Seperti yang dialami oleh dua orang anak remaja yang bernama Dina dan Santi (nama samara). Dina 
mengatakan ketika dia dengan kekasihnya melakukan seks bebas ternyata dia kedapatan hamil (2) Aborsi. Seperti yang dialami oleh Santi, ketika terjadi kehamilan dan tidak menginginkan hal ini terjadi hal yang dilakukan adalah melakukan aborsi, sebagaimana wawancara yang dilakukan penulis dengan ibu Rina dimana dia mengatakan bahwa remaja ini yang adalah anak temannya melakukan aborsi karena ketahuan bahwa ia hamil ini disebabkan ia dengan kekasihnya melakukan hubungan seks dan gadis ini hamil sedangkan mereka masih duduk di bangku SMP maka jalan keluar yang diambil adalah melakukan aborsi dengan bantuan seorang dukun kampung. ${ }^{17}$ Oleh karena itu dapat disimpulkan bahwa ketika melakukan seks bebas maka akan mengalami akibat seacra fisik yaitu kehamilan yang tidak diinginkan dan untuk menutupi agar tidak diketahui oleh orang banyak maka berlanjut pada melakukan aborsi.

Kedua, Mempengaruhi kejiwaan serta perilaku seperti ketika melakukan hubungan seksual maka menimbulkan rasa malu, bersalah bahkan ada rasa ingin bunuh diri. Seperti Santi merasa tertuduh karena sudah menggugurkan dan merasa takut karena sudah membunuh. Dina merasa malu, menyesal, ingin menyendiri karena telah hamil, Idan merasa bersalah dan menyesal, Rini merasa bersalah, menyesal dan stres, Stela merasa tertekan, ingin bunuh diri serta membuat tidak bergairah dalam belajar dan akhirnya putus sekolah. ${ }^{18}$

Jadi, dari hasil wawancara yang dilakukan oleh penulis. Maka hal yang dialami ketika melakukan hubungan seks bebas adalah bahaya perilaku dan kejiwaan seperti stres, merasa malu karena sudah bersalah, cenderung ingin menyendiri, merasa tidak berharga dan ingin bunuh diri, menjadi malas untuk ke sekolah.

Ketiga, Seks bebas mengakibatkan bahaya sosial, seperti diperguncingkan, jadi bahan pembicaraan, dikucilkan dan menimbulkan aib bagi pribadi dan keluarga. Seperti yang dialami oleh Dina (nama samaran) bahwa ketika dia melakukan hubungan seks dengan kekasihnya dan akhirnya itu mengakibatkan kehamilan baginya maka jalan keluar yang diambil ialah mereka harus menikah agar keluarga tidak menjadi malu dan ini juga cara untuk menutup aib keluarga karena merasa malu dengan keadaan yang dialami oleh dina. ${ }^{19}$ Hal yang sama juga oleh santi (nama samaran), dia melakukan aborsi karena ketahuan bahwa dirinya telah hamil dan yang mengetahuinya adalah ibu dan seorang tetangga, karena takut ketahuan oleh ayah serta keluarga yang

\footnotetext{
${ }^{17}$ Rina Puasa, Percakapan telepon dengan penulis, 12 Mei 2012.

${ }^{18}$ Santi, Dina, Idan, Rini, Stela, Percakapan telepon dengan penulis Airmadidi 2012.

${ }^{19}$ Dina (nama samaran), Percakapan telepon dengan penulis, 22 Mei 2012.
} 
lain dan masyarakat maka mereka memutuskan untuk melakukan aborsi, karena waktu itu dia masih duduk dibangku SMP. Jadi seks bebas juga dapat mengakibatkan remaja ini mempengaruhi kehidupan bersosial remaja, dimana hal ini menjadi bahan perguncingan dan pembicaraan dalam lingkungan, karena ketahuan hamil dan ada rasa tertolak dari pihak keluarga akibat terjadi kehamilan sehingga untuk menutupi agar jangan sampai semua orang mengetahuinya maka jalan keluar yang diambil adalah melakukan aborsi.

Keempat, Seks bebas juga dapat mengakibatkan melemahnya perekonomian. Sesuai wawancara penulis dengan salah satu orang tua bahwa ketika anak melakukan hubungan seks dan akhirnya menikah ataupun harus bertanggung jawab memelihara anaknya, tentunya anak akan kehilangan masa depan, dikarenakan putus sekolah dan tentunya kurang mendapatkan tempat untuk pekerjaan dan hal ini akan membuat mereka lemah dalam ekonomi. ${ }^{20}$ Seks bebas juga dapat mempengaruhi kehidupan ekonomi remaja yang melakukannya, karena masih duduk di dunia pendidikan dan masih terlalu dini akan mengakibatkan hilangnya masa depan dan tentunya mempengaruhi ekonomi karena tidak memiliki modal atau pegangan dalam hal pendidikan yang mendukung untuk mendapatkan pekerjaan.

Dari hasil analisis di atas maka sebaiknya orang tua harus bertindak terlebih dahulu untuk mencegah agar anak remajanya tidak sampai terjebak atau terlibat dalam pergaulan bebas dalam hal ini seks pranikah, seperti:

Pertama, Remaja perlu mendapat pendidikan moral dan agama yang relevan dengan kehidupan mereka. Membekali anak dengan dasar moral dan agama. Dari wawancara penulis dengan Rina selaku orang tua salah satu remaja dia berkata bahwa ia telah mengajarkan kepada anakanaknya untuk memprioritaskan hubungan dengan Tuhan lewat ibadah baik di rumah maupun di gereja. ${ }^{21}$

Kedua, Orang tua perlu memberikan kepada anak pendidikan seks yang dilakukan sejak dini terhadap anak. Sebagaimana wawancara penulis dengan Gayu Kamalaheng bahwa peranan orang tua sangat diperlukan dalam memberikan informasi dan bimbingan tentang seksualitas kepada anak- anak. ${ }^{22} \mathrm{Jadi}$, selaku orang tua mereka memberikan penjelasan- penjelasan kepada anak mengenai seksualitas anak, sehingga anak dapat mengerti dan menjaga anggota tubuhnya dengan baik.

\footnotetext{
${ }^{20}$ Lely B, Percakapan telepon dengan Penulis, 23 Mei 2012.

${ }^{21}$ Rina Puasa, percakapan telepon dengan penulis, 27 Mei 2012.

${ }^{22}$ Gayu Kamalaheng, percakapan telepon dengan penulis, 17 Mei 2012.
} 
Ketiga, Orang tua harus menyediakan waktu untuk remaja. Hal tersebut sangat penting untuk mencegah seks pranikah. Semua kegiatan anak sebaiknya dipantau, sehingga apabila ada indikasi menyimpang, bisa segera diperbaiki. Sebagaimana wawancara penulis dengan Febe Sutanto selaku orang tua bahwa, ketika anaknya memasuki masa remaja maka pengawasan serta perhatian lebih ditingkatkan, baik dalam hal belajar maupun dalam hal pergaulan anaknya. Sebagai orang tua beliau berusaha untuk mengenal siapa saja teman-teman dari anaknya, karena ini akan membantu ibu Febe untuk tetap mengontrol dan mengawasi pergaulan anaknya di luar rumah. ${ }^{23}$ Mengenal dan menjalin komunikasi dengan teman anak, merupakan salah satu jalan untuk mengetahui apa yang remaja kerjakan di luar rumah begitu pun

memberi waktu yang berkualitas untuk berbincang mengenai kegiatan anak dan permasalahanya di luar rumah adalah tindakan preventif yang perlu dilakukan oleh orang tua yang bijak dalam menyikapi perkembangan remaja.

Keempat, Orang tua harus mengetahui kebutuhan emosional anak. Kebutuhan emosianal yang utama pada anak remaja adalah cinta. Memberi cinta kepada remaja adalah tindakan nyata orang tua yang peduli kepada pertumbuhan emosianal anak. Sebagaimana wawancara penulis dengan Maria Tabinaung selaku orang tua salah satu remaja, bahwa dia memberikan kasih sayang kepada anaknya dengan cara memperhatikan apa yang menjadi kebutuhan anak, serta memberikan keluasan kepada anak untuk bisa memilih apa yang menjadi keinginan atau cita- cita anaknya. ${ }^{24}$ Ekspresi cinta orang tua kepada remaja dialirkan dengan ketulusan tanpa pemaksaan kehendak sehingga remaja mendapatkan teladan cara mengasihi tanpa pamrih. Setiap tindakan remaja yang didasarkan pada cinta kasih akan memberi dampak positif bagi emosionalnya dan dengan sendirinya akan terpancar dalam pergaulannya. Sehingga setiap orang yang bertemu dengan dirinya akan mengalami hal yang sama.

Kelima, orang tua harus menjadikan anak remajanya seperti seorang teman atau sahabat, lewat wawancara penulis dengan Rina selaku orang tua, dimana dia menjadikan anak remajanya seperti seorang teman, sehingga komunikasi yang dilakukan antara anak dan orang tua menjadi lancar dan terbuka, tidak ada yang ditutupi. Orang tua mengajarkan kepada anak untuk terbuka dan tidak merasa takut untuk menceritakan apa yang terjadi dalam diri anak. ${ }^{25}$ Awal dari keterbukaan seorang

\footnotetext{
${ }^{23}$ Febe Sutanto, Percakapan telepon dengan penulis, 12 Mei 2012.

${ }^{24}$ Maria Tabinaung, percakapan telepon dengan penulis,10 mei 2012.

${ }^{25}$ Rina Puasa, percakapan telepon dengan penulis, 27 Mei 2012.
} 
remaja adalah pada saat remaja menganggap bahwa orang tuanya dapat dijadikan sebagai teman dan sahabat untuk mencurahkan isi hatinya. Sehingga akan timbul rasa percaya kepada orang tua untuk berbagi cerita dan mengkomunikasikan apa saja yang menjadi ganjalan atau pertanyaan yang timbul dalam benak seorang remaja tentang perkembangan dan pergaulannya.

\section{PENUTUP}

\section{Kesimpulan}

Faktor pemicu yang menyebabkan remaja jatuh dalam pergaulan bebas adalah (1) Pola asuh orang tua. Pada umumnya pola asuh orang tua mengikuti tradisi yang telah ada yaitu membesarkan anak dan member fasilitas pendidikan formal, tetapi tidak memperhitungkan kebutuhan perkembangan anak yang memerlukan komunikasi tentang pendidikan seks untuk membentengi dirinya dari akibat pergaulan bebas. Karena itu dianggap tidak perlu atau "tabu" diperbincangkan sebelum sebelum anak dewasa atau menikah. (2) Perkembangan teknologi. Remaja yang tidak mendapatkan ppendidikan seks dari orang tua mudah tergiur dan terjebak oleh informasi dari dunia teknologi karena apa yang mereka dapatkan dari informasi yang terus berkembang diluar dan akibatnya teknologi tidak lagi sebagai pemberi informasi tetapi sebagai "panutan" yang menjawab kebutuhan remaja. (3) Teman sebaya. Ikatan yang kuat antara remaja dengan teman sebaya serta lingkungan mereka yang menghalalkan segala cara untuk menikmati masa remaja dapat membawa remaja kepada pergaulan bebas. Kebiasaan ikut-ikutan kepada teman sebaya yang melakukan hal- hal yang salah mengakibatkan remaja tidak dapat menolak masuk dalam pergaulan bebas karena takut di musuhi teman- teman atau di jauhi oleh lingkungan. (4) Diri sendiri. Perkembangan fisik yang diringi dengan pertumbuhan horman membuat remaja "ingin tahu" mengapa demikian?. Tetapi karena minimnya pendidikan seks yang di dapat akibatnya remaja membangun penilaiannya sendiri tentang perkembangan tersebut dan memuaskan keingin tahuannya dengan malakukan penyimpangan seks, dalam hal ini tidak ada pengendalian diri karena ketidaktahuan.

Bahaya- bahaya dari pergaulan bebas akan mengakibatkan :

Pertama, pergaulan bebas akan berdampak pada bahaya fisik seperti penyakit menular seksual yang akan membuat pelakunya menderita seumur hidup. 
Kedua, seks bebas akan mengakibatkan kehamilan yang tidak diinginkan dan akan mengakibatkan kematian baik janin maupun ibu yang mengandung karena ketika kehamilan yang tidak diinginkan terjadi sehingga terjadinya aborsi.

Ketiga, seks bebas akan mempengaruhi psikis seseorang, seperti rasa malu, tidak berharga, putus asa sampai ingin mengakhiri hidup atau bunuh diri, dihantui rasa bersalah yang berkepanjangan, menyesali diri, yang membuat tidak bergairah dan tidak memiliki pengharapan kedepan.

Keempat, pergaulan bebas di kalangan remaja akan berdampak kepada ekonomi yang lemah, disebabkan remaja putus sekolah dan tidak bisa bekerja atau menghidupi keluarga karena menikah secara dini dan belum siap mem,ikul tanggung jawab.

\section{Saran-Saran}

Adapun saran- saran dari penulis sebagai masukan kepada orang tua dan gereja dalam hal memberikan tindakan preventif terhadap pergaulan bebas remaja adalah:

Pertama, Orang tua harus memberikan teladan kepada anak remajanya untuk menumbuhkan iman percaya kepada Tuhan lewat mezbah keluarga, sehingga spiritual anak bertumbuh sejak dini dalam keluarga dan mengajarkan kepada anak untuk menjaga kekudusan hidupnya.

Kedua, Orang tua sudah sejak awal memberikan pendidikan seks kepada anak, sehingga anak sudah mengerti mengenai anggota- anggota tubuhnya dan menghargainya.

Ketiga, Orang tua perlu memiliki wawasan yang luas mengenai perkembangan remaja dan tidak menutup mata mengenai dunia remaja.

Keempat, Gereja mampu bekerja sama dengan orang tua dalam menumbuhkan iman percaya remaja lewat kegiatan- kegiatan kerohanian di gereja serta melibatkan remaja dalam kegiatan tersebut.

Kelima, Gereja memberikan fasilitas kepada remaja dalam mengembangkan talenta yang ada pada remaja.

Keenam, Gereja juga mampu memberikan pengajaran yang relevan sesuai dengan dunia remaja, sehingga remaja tidak bosan ketika berada dipersekutuan ibadah remaja atau kegiatan gereja. 


\section{KEPUSTAKAAN}

Alkitab

Alkitab. Jakarta : Penerbit Lembaga Alkitab Indonesia, 2004.

\section{Kamus- Kamus}

Kamus Umum Bahasa Indonesia, Jakarta: Pustaka Sinar Harapan. 1994, Kamus Besar Bahasa Indonesia, edisi ketiga. Departemen Pendidikan Nasional, Jakarta: Balai Pustaka, 2001.

Kamus Kedokteran, Jakarta: Djambatan, 2000.

Kamus Kedokteran, Jakarta: Buku Kedokteran (EGC) Medical Publisher, 1900.

\section{Buku-Buku Penunjang}

Arterburn, Stephen \& Jim Burns. Arahkan Dengan Jitu. Yogyakarta: ANDI, 2006.

Borrong Robert P. Etika Seksual Kontemporer. Bandung: INK Media, 2006.

Brownlee, Malcolm. Hai pemuda Pilihlah!. Jakarta: BPK Gunung Mulia, 1986.

Buchana, Margaret. Parenting With Purpose. Jakarta: Metanoia Publishing, 2009.

Chapman, Gary \& Ross Campbell, M.D. Lima Bahasa Kasih untuk AnakAnak. Batam : Interaksara, 2000.

Dowel, Mc. Hilary. Kunjungan Ke Planet Remaja Favorit Ke-2. Bandung: Yayasan Kalam Hidup, 2004.

Gunarsa, Singgih D. Dr \& Dra. Ny. Y Singgih D.Gunarsa. Psikologi Perkembangan Anak dan remaja. Jakarta: BPK. Gunung Muli, 1991.

1991. . Psikologi Untuk Muda-Mudi. Jakarta: BPK. Gunung Mulia,

Hadi, Sutrisno. Statistik. Yogyakarta: FIP-IKIP, 1975.

Health, Stanley. W. Teologi Pendidikan Anak. Bandung: Yayasan Kalam Hidup, 2005.

Hinckley, K.C. Kompas Kehidupan Kristen. Bandung: Yayasan kalam Hidu, 1989.

Kartono, Kartini. Psikologi Anak. Bandung: Mandar Maju, 1995.

Kenny, James \& Mary Kenny. Dari Bayi-Dewasa. Jakarta : BPK. Gunung Mulia, 1991.

Laufer, Ruth. Metode- Metode Kreatif Untuk Pelayanana Remaja. Yayasan Persekutuan Pekabaran Injil Indonesia, 1986. 
Hadari Martini, Nawawi Hadari. Instrumen Penelitian Bidang Sosial. Yogyakarta: Gajah Mada University Press, 1992.

Ndraha, Roswitha \& Julianto Simanjuntak. 9 Masalah Utama remaja. Tangerang: $\quad$ Yayasan Peduli Konseling Indonesia, 2009.

Reksadjaja, Bill S. Manusia Dalam Lingkungan. Departemen Pendidikan Dan Kebudayaan Direktoral Jendral pendidikan Dan kebudayaan, 1979.

Richards, Larry. Berpacaran Sampai Dimana Batasnya?. Jakarta: BPK Gunung Mulia, 1986.

Sangarimbun, Masri \& Sofian Effendi. Metode Penelitian Survai. Jakarta: LP3Es,1986, 192.

Simanjuntak, Julianto \& Roswitha Ndraha. Mendidik Anak Sesuai Zaman dan Kemampuannya. Tanggerang: Layanan LK3, 2007. Mendidik Anak Utuh Menuai Keturunan Tangguh. Tanggerang: Yayasan LK3, 2010.

Singarimbun, Masri \& Sofian Effendi. Metode Penelitian Survai. Jakarta: Lembaga Penelitian, Pendidikan dan Penerangan Ekonomi dan Sosial, 1986.

Soekanto, Soerjono. SH, MA. Remaja dan Masalah-Masalahnya. Yogyakarta: BPK Gunung Mulia, 1982.

Stewart, Ed. Bagaimana Menjangkau Remaja. Bandung : Yayasan Kalam Hidup, 1999.

Subagyo, Andreas B. Pengantar Riset Kualitatif dan Kuantitatif. Bandung: Yayasan Kalam Hidup, 2004.

Surbakti, E.B. Awas Tayangan Televisi. Jakarta: Gramedia, 2008.

Usman Husain. Metodologi Penelitian Sosial. Jakarta: Bumi Aksara, 1998.

Wijaya, Andik. Julianto Simanjuntak dan Roswitha Ndraha. Transformasi Perilaku Seksual. Jakarta: Institut Konseling LK3, 2007.

Yuanita, Sari. Fenomena dan Tantangan Remaja Menjelang Dewasa. Yogyakarta: Brilliant Books, 2011.

Diktat

Grinell, Ann "Diktat Love, Seks dan Narkoba." STT Jaffray, Makassar, 30 April 2010.

\section{Ceramah}

Leonardy, Rudy. Divisi Obstetri dan Genekologi Sosial Bagian Universitas Hasanudin. Ceramah Kapel STT Jaffray Makassar Rabu 18 April 2012.

Erickson, Dave. "Penyembuhan Luka Batin". Ceramah pada Ibadah Caphel STT Jaffray, Makassar 28 Maret 2012. 
Aborsi dan Pergaulan Bebas Remaja Yang Mengkwatirkan diakses tanggal 02 mei 2012 tersedia

http://sosbud.kompasiana.com/2011/04/17/aborsi-dan-pergaulan- bebasremaja-yang- mengkwatirkan/.

Artikel Pendukung Blog dr. Iwan, Beberapa jenis penyakit yang dapat menular dari seks dan gejala-gejalanya, tanggal 30 Mei 2012 tersedia di www.indomp3z.us/showthread.php/49991-Beberapa-jenispenyakit-yang-dapat-menular-dari-seks-dan-gejala-gejalanya.

Pergaulan Kebas di Kalangan Remaja di akses taggal 24 April 2012 tersedia http://edukasi.kompasiana.com/2010/09/25/pergaulan-bebas-dikalangan remaja.

Resiko Aborsi Diakses pada tanggal 31 Mei 2012 tersedia di http://www.aborsi.org/resiko.htm.

Suara pembaruan memihak kebenaran di akses tgl 25 maret 2012 tersedia http://www.suarapembaruan.com/tajukrencana/keluargabenteng-seks- pranikah/1541.

Puasa, Rina. Percakapan Via Telepon.

Wawancara

B, Lely. Percakapan Via Telepon.

Kamalaheng, Gayu. Percakapan Via Telepon.

Sutanto, Febe. Percakapan Via Telepon.

Sipera, Tia. Percakapan Via Telepon.

Dina (nama samaran). Percakapan Via telepon.

Santi (nama samaran). Percakapan Via Telepon.

Idan (nama samaran). Percakapan Via Telepon.

Rini (nama samaran). Percakapan Via Telepon.

Stela (nama samara). Percakapan Via Telepon. 